Satrio Dwi Naryo, Moses Glorino Rumambo Pandin

Universitas Airlangga

Airlangga St. 4-6, Airlangga, District Gubeng, Surabaya City, East Java 60115.

satrio.dwi.naryo-2020@fib.unair.ac.id, moses.glorino@fib.unair.ac.id

\title{
BOOK REVIEW: \\ "ABC FILSAFAT MENGENAL CARA BERFIKIR MAJU UNTUK DIRI SENDIRI DAN DUNIA" (ABC PHILOSOPHY KNOWS HOW TO THINK FORWARD FOR YOURSELF AND THE WORLD)
}

\author{
Daffin Davanka : Yogyakarta ; 2021 : 978-623-7778-57-8 ; 214 PAGES
}

Philosophy has been known by many in the general public. However, many of the people do not know more about philosophy. Daffin Davanka has a purpose with this book can introduce philosophy to the general public and early enthusiasts who are interested in entering the world of development and philosophical thinking further

The author wrote book for the general public and early enthusiasts who wanted to explore into the world of philosophy. In book enough to provide information and insight about the development and thinking as a whole. The content of book is compiled with a strong historical approach in order to track the development of basic philosophical thoughts and methods. This book records information and insights on the development of philosophical thought and methods and relates it with the present condition, also found in other chapters presenting discussions showing that philosophy has developed widely and describes the continuity of thought in aspects of philosophical history to research philosophy is quite diverse.

The reviewers' presentation above is essential and important to be read by the public or the general public. Because on this book has introduced the science of philosophy through the medium of books he wrote. This book is highly recommended because the light, dense and directed reading makes the reader more comfortable understanding it and eliminates confusion and skepticism of philosophy itself.

Based on the condition of people who do not know much about the world of philosophy, the author wants to convey and introduce the world of philosophy with the work of his book entitled ABC Philosophy "Knowing How to Think Forward for Yourself and the World". The book has explained clearly and densely what is needed by the reader, which book has explained from the understanding of philosophy itself to the development and thinking of philosophy and the needs of audiences or novice readers who are interested or interested in entering the world of philosophy deeper.

Overall, the book a author presents quite complete and directed information. Each sub-chapter has a different sub-chapter of discussion. In the sub-chapter, the language is explained in an organized manner that makes the reader understand how philosophy was formed and how philosophy was carried out. There was a time in ancient philosophy and the figures who expressed and presented related to philosophy's thought and development. There is a connection or relevance to the present condition. The book is very informative and educational for beginners who will delve deeper into the world of philosophy.

This book has a huge influence on its readers. The reader's questions have largely been answered on the book within author explains what the reader is asking clearly, and it dispels the ambiguous and skeptical view of philosophy. One of them in chapter 4 which discusses the 
nationalists, there is a question in the sub-chapter of the discussion on meditation which in the sub-chapter questions "How can we be sure that our sensory experience in the outside world is not really a dream". The author answers the question in the fourth paragraph of page 56, saying that "Sensory experience is ruled out because experience is uncertain and not enough as justification of a science" and gives one example of a claim from Descartes through reasoning that believes that $2+2=4$. In this case Descartes imagines that the devil can deceive to always say $2+2=4$ is true when in fact it is wrong.

The evidence uses is quite strong in reinforcing the theory he presented. In presenting a theory, and lists the validity of the theory by placing who came up with the theory and provides an example of a view of the theory that has been described earlier. Obviously, the evidence presented in the book, which the source of the evidence comes from leading experts in the theory. No doubt on the validity of the basis of evidence written by author.

In writing this book, author uses a language style that is light and understandable to readers. What we know is that most people bother reading philosophy books is a scourge. Due to the use of a style of language that is not understood by the general public and the discussion is heavy. Not with a book called ABC Philosophy "Knowing How to Think Forward for Yourself and the World" which is very light discussion especially for beginners who want to know the world of philosophy as a prefix.

\section{REFERENCE}

1. Daffin Davanka. ABC Filsafat Mengenai Cara Berfikir Maju untuk Diri Sendiri. 1st ed. Yogyakarta: Bright Publisher; 2021. 214 p.

AUTHOR: Daffin Davanka is the person behind abc's book Philosophy on How to Think Forward for Yourself. He was born in Tanjung Uban on December 4, 1990. He last studied at the Faculty of Social and Political Sciences at one of the universities in Yogyakarta. During college, he was very active and participated in the study and discussion of critical thinking philosophy until Daffin Davanka produced several works in the form of essays on personal blogs. One of them is the book ABC Philosophy On How to Think Forward for Yourself. 